\title{
The pursuit of counterfeited luxury: An examination of the negative side effects of close consumer-brand connections
}

Article in Journal of Business Research · April 2015

DOI: 10.1016/j.jbusres.2015.02.022

CITATIONS

11

3 authors:

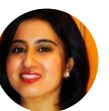

Praneet Randhawa

University of Baltimore

6 PUBLICATIONS 21 CITATIONS

SEE PROFILE

\section{Clay Voorhees}

Michigan State University

35 PUBLICATIONS 850 CITATIONS

SEE PROFILE
READS

118
Roger Calantone

Michigan State University

240 PUBLICATIONS $\quad \mathbf{1 4 , 6 1 7}$ CITATIONS

SEE PROFILE

Some of the authors of this publication are also working on these related projects: 


\title{
The pursuit of counterfeited luxury: An examination of the negative side effects of close consumer-brand connections
}

\author{
Praneet Randhawa $^{\text {a }}$, Roger J. Calantone ${ }^{\mathrm{b}}$, Clay M. Voorhees ${ }^{\mathrm{b}, *}$ \\ a Department of Marketing and Entrepreneurship, Merrick School of Business, University of Baltimore, United States \\ b Department of Marketing, The Eli Broad Graduate School of Management, N370 North Business Complex, Michigan State University, East Lansing, MI 48824, United States
}

\section{A R T I C L E I N F O}

\section{Article history:}

Received 10 February 2014

Received in revised form 24 February 2015

Accepted 25 February 2015

Available online 24 April 2015

\section{Keywords:}

Luxury brand counterfeits

Self-brand connection

Impulsive buying

Value consciousness

Openness to experience

\begin{abstract}
A B S T R A C T
Over the past two decades, the counterfeiting industry has cost U.S. manufacturers over \$200 billion. In this study, we extend current research on consumers' willingness to purchase counterfeit products by demonstrating that consumers' need to build their self-concept via selfbrand connection directly impact consumers' willingness to purchase counterfeits and these effects are moderated by value consciousness and openness to experience. As a result, our findings move beyond simple assessments of the impact of demographics and social norms to provide a deeper understanding of why and when consumers purchase counterfeit goods. The findings provide new insights that luxury brand managers could leverage to proactively combat counterfeiting and begin curtailing their losses due to the sale of fake goods.
\end{abstract}

(C) 2015 Elsevier Inc. All rights reserved.

\section{Introduction}

Counterfeiting of brand name goods has increased by more than $10,000 \%$ in the past two decades and costs U.S. manufacturers over $\$ 200$ billion annually (International AntiCounterfeiting Coalition, 2012). Counterfeit goods, comprising any illegal impersonation of branded goods, are growing in popularity (particularly for luxury brands) due to the relative ease of manufacturing and the spike in consumer demand. Initial investigations of counterfeit purchase have demonstrated that luxury brands' engender counterfeiting (Cordell, Wongtada, \& Kieschnick, 1996) that consumers' buy to fulfill their need for social assimilation (see Han, Nunes, \& Drèze, 2010; Wilcox, Hyeong, \& Sen, 2009). While these studies provide a good starting point for developing our understanding of the role of luxury brands in counterfeiting, more research is needed to understand how luxury brands engender counterfeiting. Luxury brand counterfeit (LBC) purchase not only represents the aspects of the product and the brand (Bian \& Moutinho, 2009; Eisend \& Schuchert-Güler, 2006), but also the consumer. Understanding the connection between a consumer and a brand is vital for improving our understanding of the proliferation of LBC.

The luxury consumption literature shows that consumers buy luxury products to shape or reflect their self-concept (Puntoni, 2001; Wiedmann, Hennigs, \& Siebels, 2009). Counterfeit literature, on the other hand, shows that consumers buy counterfeit products to send a

\footnotetext{
* Corresponding author. Tel.: + 15174326469.

E-mail address: voorhees@broad.msu.edu (C.M. Voorhees).
}

positive signal to others including themselves (Bodner \& Prelec, 2002; Wilcox, Hyeong, \& Sen, 2009). While research in both these respective areas provides some solid insight into how consumers view luxury goods and counterfeits, there are still certain questions that are left unanswered to truly integrate these streams. To address this issue, we first integrate and extend recent research in both areas by first exploring if consumers buy LBC products to fulfill certain psychological needs such as the ability to construct and/or reflect their self-concept (or image) to others. Moreover, we examine the role that situational personality traits play in altering the relationship between a consumers' connection to a brand and willingness to purchase LBC products.

By focusing on both consumer-brand relationships and consumer personality traits, we provide an improved understanding into this complex purchase process. In doing so, we offer three unique contributions to the literature. First, our results demonstrate that it is not only a consumer's desire to build their self-concept that attracts them toward LBC, but there are also certain personality traits that impact such an attraction. Second, we empirically demonstrate that consumer-brand relationships have a direct impact on consumer's willingness to buy LBC, hence highlighting the dark side of consumer-brand connections. Third, we take a step further to demonstrate that value-consciousness and impulsiveness personality factors positively influence consumers' LBC purchase process, while openness to experience has a negative impact. The results of this study provide a fresh perspective on the complex mechanisms associated with LBC product purchase.

In the following section, we review the literature, and develop hypotheses. 


\section{Conceptual background and hypothesis development}

From a consumer's perspective, counterfeiting can be either deceptive or non-deceptive (Grossman \& Shapiro, 1988). Non-deceptive counterfeiting, the focus of this study, occurs when consumers knowingly buy a product that they recognize is an imitation of a highly valued brand. Non-deceptive counterfeiting is mainly prevalent in the luxury goods market (Nia \& Zaichkowsky, 2000), and largely argued to be driven by consumer demand (Bloch, Bush, \& Campbell, 1993; Cordell et al., 1996). Research on non-deceptive counterfeiting has attributed counterfeit consumption proliferation to the following three reasons (Eisend \& Schuchert-Güler, 2006): price affordability and/or product feature preferences (e.g., Albers-Miller, 1999; Penz \& Stottinger, 2005; Poddar, Foreman, Banerjee, \& Ellen, 2012), social and cultural influence (e.g., Chakraborty, Allred, \& Bristol, 1996; Han et al., 2010; Hoe, Hogg, \& Hart, 2003; Lai \& Zaichkowsky, 1999; Leisen \& Nill, 2001; Wilcox, Hyeong, \& Sen, 2009), and consumer socioeconomic status (e.g., Bloch et al., 1993; Cheung \& Prendergast, 2006; Chuchinprakarn, 2003). Recent research has started explored the role of luxury brand in the demand of counterfeit products (e.g., Bian \& Moutinho, 2009; Turunen \& Laaksonen, 2011). These studies in general argue that ignoring the role of a luxury brand limits the understanding of counterfeit product proliferation because the brand plays an integral role in consumers' demand for luxury brand counterfeit products. Turunen and Laaksonen's (2011) qualitative study shows that consumers consider LBCs as embodiment of real luxury brands. Bian and Moutinho (2009) also found that the match between consumer- and brand-personalities has a positive influence on consumer's tendency to buy LBC. While these studies establish the importance of luxury brands in LBC, they do not explore the psychology behind consumers' attraction to LBC. We posit that luxury brands play a critical role in shaping consumers' preference for LBC because they fulfill their psychological desire to achieve the symbolic meaning associated with the particular luxury brand such as the desire to construct or reflect their self-concept to others. The conceptual model and expected directionality are presented in Fig. 1. Each of these directional effects is elaborated on in the following section.

\subsection{The effect of self-brand connection}

Brands have the ability to both influence customer purchase decisions and shape consumer identities (Aaker, 1997; Escalas \& Bettman, 2005; Richins, 1994). According to Escalas and Bettman (2005, p. 378), "when brand associations are used to construct the self or to communicate the self-concept to others, a connection is formed with the brand." The authors label this connection with the brand as self- brand connection (SBC). Material possessions in the form of luxury brands help consumers satisfy different psychological needs such as creating and communicating their self-concept (Belk, 1988; Escalas \& Bettman, 2005; Sirgy, 1982). We define self-concept as the "totality of the individual's thoughts and feelings having reference to himself as an object" (Rosenberg, 1979, p. 7).

Consumers adopt different techniques, such as conforming to social norms, flattery, self-promotion (Escalas \& Bettman, 2003; Fiske \& Taylor, 1991), or acting dishonestly (Mazar, Amir, \& Ariely, 2008) to accomplish the objective of signaling or shaping identities. Among the different techniques used by the customers, acting dishonestly for signaling identities is an intriguing consumer behavior phenomenon with strong implications for counterfeit consumer behavior. Mazar et al. (2008, p. 633) argue that customers "behave dishonestly enough to profit but honestly enough to delude themselves of their own integrity. A little bit of dishonesty gives a taste of profit without spoiling a positive self-view." This suggests that some customers deliberately carry out dishonest acts with the aim of maximizing their return while reducing the investment cost, and in the process do not question their self-concept. Deliberate dishonest acts in retailing, such as wardrobing (the act of purchasing, using and then returning the used clothing or accessories), cost U.S. retailers $\$ 16$ billion annually (Speights \& Hilinski, 2005), and consumers do not consider acts to be unethical or immoral (Rosenbaum, Ronald, \& Wooldridge, 2011). Similarly, it can be argued that many consumers are tempted to buy counterfeit products because, according to them, the act of buying counterfeit products falls within the boundaries of acceptable dishonesty and allows them to unbundle the status and quality attributes of a high status brand without paying the high price (Bian \& Moutinho, 2009; Grossman \& Shapiro, 1988). Therefore, the following hypothesis:

Hypothesis 1. SBC has a direct positive effect on the willingness to buy LBC.

2.2. The effects of value consciousness, impulsive buying, and openness to experience

Value consciousness (VC) is defined as a concern for price keeping in mind the quality received (Lichtenstein, Ridgway, \& Netemeyer, 1993). A consumer's perceived value of a product is considered to be an influential driver of their purchase decision. Research shows that when consumers find better value in a product compared to other product options, their intention to buy that product increases (Dodds, Monroe, \& Grewal, 1991). This experience provides them with a

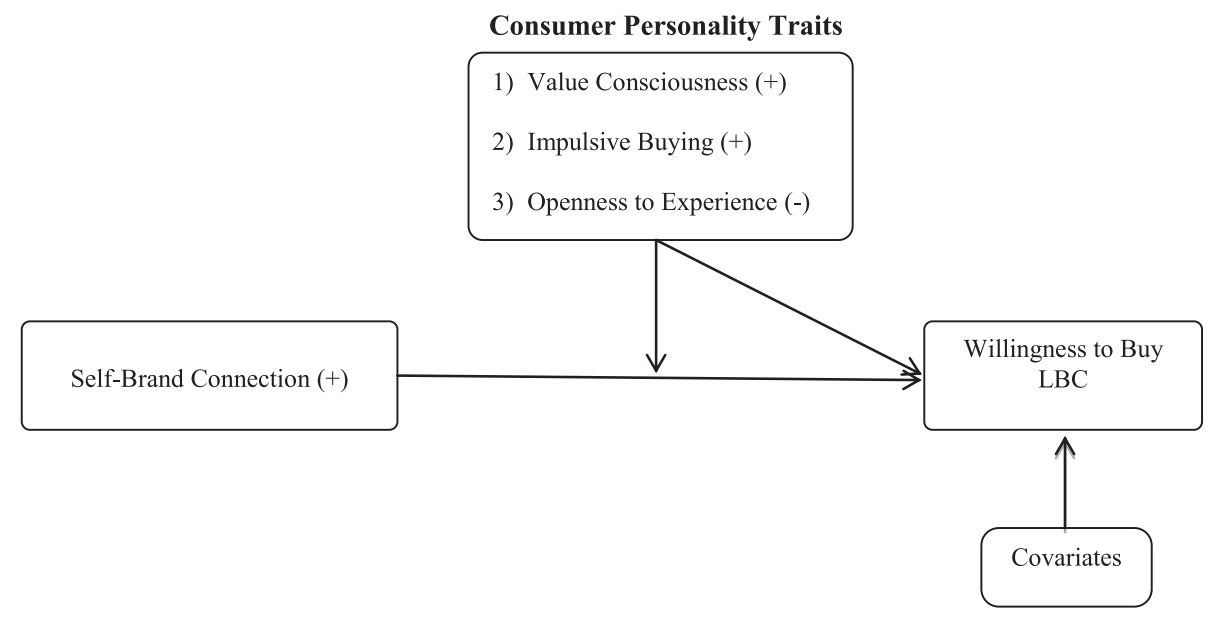

Fig. 1. Conceptual model. 
feeling of being a "smart shopper" (Lichtenstein et al., 1993). Phau and Teah (2009) found that value conscious consumers have a positive attitude toward counterfeit products. When consumers encounter counterfeit products that seem to provide high value at low price, their tendency to buy such a product increases. Our argument shadows Lichtenstein, Netemeyer, and Burton's (1990, p. 56) reasoning that, "for most people price and quality are the most salient 'give and get' components," and in any given purchase situation where consumers find the salient "give and take" component, their willingness to purchase the product will be high. Therefore, the following is hypothesized:

Hypothesis 2. Value-consciousness has a direct, positive effect on the willingness to buy LBC.

Impulsive buying behavior is a widely known phenomenon in the United States. According to Kacen and Lee (2002, p. 163), it is defined as, "a sudden, compelling, hedonically complex purchasing behavior in which the rapidity of the impulse purchase decision process precludes thoughtful, deliberate consideration of all information and choice alternatives." Consumer impulsivity is argued to arise from the tendency to overvalue benefits and undervalue long-term effects (Ramanathan \& Menon, 2006). According to Stern (1962), impulse buying is largely dependent on resources such as money, time, and physical and mental effort, with money exerting the most direct impact on the purchase decision (Kukar-Kinney, Ridgway, \& Monroe, 2012). Prior research also shows that impulsive buyers seek pleasure in finding value deals because such deals make them feel less guilty in engaging in impulse purchases (Kukar-Kinney et al., 2012). This suggests that if a consumer gets easy access to a product where the expenditure of resources in the form money, time, and the physical and mental effort is low, then the likelihood of an impulse purchase is greater (Stern, 1962).Therefore, it can be argued that when consumers with impulsive buying trait encounter counterfeit products, the likelihood of buying such a product may be high. Hence, it is hypothesized,

Hypothesis 3. Impulsive buying behavior has a direct, positive effect on the willingness to buy LBC.

Openness to experience refers to a person who is curious, creative, original and imaginative, finds novel solutions, and enjoys new experiences (Costa \& McCrae, 1992; McCrae, 1987). According to Costa and McCrae (1992), open individuals are highly motivated to find new and diverse experiences. These individuals are always actively seeking situations that expose them to unfamiliar conditions that help them find novel experiences. Additionally, in another study, McCrae and Costa (1997) claim that open individuals have absorptive capability of combining and integrating new and unrelated information. These characteristics not only allow open individuals to find novel solutions, but also allow them to make better decisions when they are exposed to unfamiliar situations. In another study, Woo, et al. (2014, p. 29) state that, "because novel stimuli can appear in the form of novel experiential stimuli (e.g., new cultural experiences) and that of original intellectual stimuli (e.g., new theories), individuals might prefer one form of novel stimulation and dislike the other form (e.g., one might enjoy traveling to exotic cultures but dislike reading new scientific findings)." Thus, it is contended that open customers are likely to engage in a counterfeiting shopping experience, but their likelihood to actually buy the product will be low. Engaging in a counterfeit shopping experience provides novel and unique experience that satisfies the curious nature of such a customer at no cost. However, purchasing and using counterfeit products does not provide novel or creative experience, rather purchasing such products runs counter to their true self of being authentic and original. Thus,we propose:

Hypothesis 4. Openness to experiences has a direct, negative effect on the willingness to buy LBC.

\subsection{Interaction effects}

Personality traits reflect enduring behaviors or responses that are consistent across situations (McCrae, 2009). This suggests that consumers with certain personality traits are expected to exhibit consistent behaviors associated with those traits irrespective of the situation, which makes exploring the interactive effects of personality traits with SBC a very meaningful endeavor. Therefore, the next set of hypotheses involves two-way interactions between SBC and consumer personality traits.

Prior research indicates the importance of the interaction between VC and brand preferences (Monroe, 1979). According to Monroe (1979), the best purchase decision is the one where the brand provides the highest ratio of quality to price for the product category. Additionally, VC is argued to influence consumers' preference for counterfeit products (Dodge, Edwards, \& Fullerton, 1996; Phau \& Teah, 2009). These findings suggest that value conscious consumers' willingness to buy a LBC is particularly high when the product embodies their self-concept and is viewed as being a good deal. There are two reasons for expecting such an interaction. First, consumers who deliberately buy counterfeit products buy them primarily for the fashion component in the form of brand image attached with the product (Tom, Garibaldi, Zeng, \& Pilcher, 1998). LBC products help consumers achieve two separate objectives: (1) it gives some consumers the opportunity to create a unique identity by using a brand that helps them separate from others, and (2) it allows some customers to assimilate with a group they desire (Wilcox, Hyeong, \& Sen, 2009). This objective is achieved by showing what the brand means rather than how the counterfeit product performs (Penz \& Stottinger, 2005). LBCs are considered to provide the prestige without paying the high price. Second, evidence shows that there are consumers who buy counterfeit products because of the value the product provides in terms of the price-quality ratio rather than just merely acquiring a brand (Geiger-Oneto, Gelb, Walker, \& Hess, 2012).Hence, the following is hypothesized:

Hypothesis 5. VC positively moderates the effect of SBC on willingness to buy LBC to the extent that the effect of SBC on the willingness to buy LBC is stronger when VC is high.

Impulsive consumption has been associated with a conflict between the desire to consume and the ability to resist it (Hoch \& Loewenstein, 1991). This conflict upsurges in situations where processing resources, such as time and money, are limited, thus enticing consumers to give in to their impulses. Moreover, prior research shows that a consumer's need to build their self-concept is linked to impulsive buying tendencies (Zhang \& Shrum, 2009), and these tendencies are higher for hedonic things such as branded products (Ramanathan \& Menon, 2006). These findings suggest that when an impulsive buyer finds a brand that is associated with their self-concept, their propensity to buy such a product may increase. Therefore, the following hypothesis is proposed:

Hypothesis 6. Impulsive buying positively moderates the effect of SBC on willingness to buy LBC to the extent that the effect of SBC on the willingness to buy LBC is stronger when impulse buying is high.

Consumers tend to choose those brands that are similar to their own personalities (Huang, Mitchell, \& Rosenaum-Elliott, 2012). McCrae's (1996) extensive review shows that the openness element of personality is associated with different social outcomes. He argues that openness is a fundamental way of approaching life that impacts both internal experience and social relationships and behaviors. This implies that openness to experience may play a role in building self-concept. As previously argued, an open consumer may be highly motivated to engage in counterfeit shopping experience, but might not be willing to engage in the actual product purchasing. In a similar vein, it is argued that open consumers, who use brands to create their self-concept by 
building SBCs, will have a lower tendency to buy counterfeit products. Our premise is in line with previous findings that open consumers tend to be loyal toward the brands they like (Lin, 2010; Matzler, Bidmon, \& Grabner-Krauter, 2006). Additionally, research shows that consumer personality interacts with brand personality because it provides a vehicle for self-expression (Fournier, 1998; Sirgy, Johar, Samli, \& Claiborne, 1991). In sum, this implies that engaging in branded counterfeit product purchase may not only lead to a clash with the true self, but may also induce a feeling of disloyalty toward the preferred brands. Thus, the following is hypothesized:

Hypothesis 7. Openness to new experiences negatively moderates the effect of SBC on willingness to buy LBC to the extent that the effect of $\mathrm{SBC}$ on the willingness to buy LBC is weaker when openness to new experiences is high.

\section{Method}

\subsection{Sampling and data collection}

Respondents were recruited via Amazon's Mechanical Turk's service. Mechanical Turk is considered to provide slightly more demographically diverse sample compared to the traditional Internet or typical American college student samples. The data obtained are considered to be at least as reliable as those gathered via the traditional data collection methods (Buhrmester, Kwang, \& Gosling, 2011). For our particular data collection, 296 consumers provided complete data that was suitable for analysis. Fifty-two percent of the sample was male and the average age was 35 years. In terms of race/ethnicity, $86 \%$ of the respondents were Caucasian, 5\% African-American, 3\% Hispanic, $4 \%$ Asian, $1.3 \%$ Native American, and $0.7 \%$ reported their race/ethnicity as "other." The data collection was restricted to the United States.

After agreeing to participate in the research study, respondents were directed to the survey instrument. The first question on the survey captured the respondents' gender and was used to direct each respondent to a gender-specific product type scenario. Specifically, men (women) were randomly directed to one of three product scenarios: (1) men's (women's) watch (Rolex), (2) men's (women's) belt (Gucci), or (3) men's wallet (women's handbag) (Louis Vuitton). The brand for each of these products was selected based on the results of a pre-test to ensure that consumer familiarity with each was sufficiently high with an average mean above 4.0 out of 5.0. Once they were assigned to one of the preceding product categories, respondents were shown pictures of the counterfeit product along with the asking price. The respondents were informed that the products in the pictures are fake and their quality is poor as compared to the original product. However, we also informed the respondents that the vendor claims the product to be of great quality. The pictures and the price of the counterfeit product were taken from a website that claimed to be selling high quality replica at cheap prices. The respondents were given the price differential between the original and the fake products. These price differentials were calculated based on the price of the original product and their corresponding fake product being sold online. Once the respondents viewed the photos of LBC they were asked to respond to a set of questions by bearing in mind both the product and brand type shown. At last, they were asked to respond a set of questions about impulsive buying, openness to experience, and demographics.

\subsection{Measures}

The independent variables predicted to impact willingness to buy counterfeit products are SBC, impulsive buying, VC, and openness to experience. In addition to the independent variables, we included measures of perceived level of affordability of the original product, prior fake product experience, propensity to buy original and authentic products, age, gender, and product types as control variables. Table 1 shows the descriptive statistics, correlation and covariance matrices for all the variables. Where possible, all established measures were used using a 5-point Likert-type scale. Table 2 provides complete detail on measures and their definitions and sources.

\subsection{Measurement model testing}

Based on guidance provided by Bagozzi and Yi (2012), we conducted a comprehensive confirmatory factor analysis to check the discriminant and convergent validities of the variables to determine model fit and construct reliability. The results are reported in Table 2 and demonstrate that all standardized loadings for items of reflective measures are large and significant (range: 0.62 to 0.93 ), in support of convergent validity. Internal consistency of reflective measures is denoted by construct reliability estimates (Fornell \& Larcker, 1981). Table 2 reveals that all constructs have reliability estimates well above the accepted level of 0.7 , thus further reasonably confirming the unidimensionality and convergent validity of the constructs. Discriminant validity was established by first examining the interconstruct correlations, which were all significantly smaller than 1.0 (Bagozzi, Yi, \& Phillips, 1991). The squared average variance extracted (AVE) for each construct was then compared with the correlations. In all cases, the squared AVE was larger than the correlations, therefore adequately confirming discriminant validity (Fornell \& Larcker, 1981). See Table 1 for the comparison. The analysis indicates a good fit for the independent variables used in the model $\left(\mathrm{CFI}=.98, \mathrm{SRMR}=.04, \mathrm{RMSEA}=.04\right.$ and $\left.\chi^{2}(220)=354, \mathrm{p}=0.00\right)$.

Table 1

Construct descriptive statistic, correlations, and covariances.

\begin{tabular}{|c|c|c|c|c|c|c|c|c|c|c|c|c|}
\hline Construct & 1 & 2 & 3 & 4 & 5 & 6 & 7 & 8 & 9 & 10 & 11 & 12 \\
\hline 1. Willingness to buy LBC & .81 & .67 & .38 & .21 & .01 & .05 & .18 & -.12 & -.27 & -1.10 & -.02 & -.00 \\
\hline 2. Value consciousness & .68 & .74 & .24 & .08 & .05 & .07 & .18 & -.06 & -.28 & -.31 & .06 & -.03 \\
\hline 3. Self-brand connection & .46 & .27 & .79 & .26 & .06 & .03 & .20 & -.08 & .15 & -.51 & .03 & -.01 \\
\hline 4. Impulsive buying & .23 & .09 & .32 & .74 & -.01 & -.02 & .08 & -.07 & -.06 & -.91 & -.04 & -.00 \\
\hline 5. Openness to experience & .01 & .07 & .10 & -.02 & .72 & .00 & .04 & -.00 & .11 & .28 & .02 & .00 \\
\hline 6. Gender & .09 & .15 & .07 & -.05 & .01 & $\mathrm{~N} / \mathrm{A}$ & -.05 & .01 & -.03 & 1.05 & .01 & -.00 \\
\hline 7. Affordability & .15 & .15 & .18 & .07 & .04 & -.03 & $\mathrm{~N} / \mathrm{A}$ & -.03 & .08 & -.02 & -.01 & -.02 \\
\hline 8. Prior fake product experience & -.24 & -.12 & -.20 & -.14 & -.00 & .06 & -.06 & $\mathrm{~N} / \mathrm{A}$ & .12 & .47 & .01 & .00 \\
\hline 9. Authentic products & -.30 & -.29 & .18 & -.07 & .15 & -.06 & .07 & .25 & $\mathrm{~N} / \mathrm{A}$ & -.13 & .01 & .02 \\
\hline 10. Age & -.10 & -.03 & -.05 & -.09 & .03 & .19 & -.00 & .09 & -.01 & $\mathrm{~N} / \mathrm{A}$ & -.08 & -.37 \\
\hline 11. Watch dummy & -.04 & .13 & .01 & -.08 & .07 & .04 & -.02 & .03 & .03 & -.02 & N/A & -.11 \\
\hline 12. Purse dummy & -.00 & -.06 & -.01 & -.01 & .00 & -.01 & -.04 & .01 & .04 & -.07 & -.50 & $\mathrm{~N} / \mathrm{A}$ \\
\hline Mean & 2.16 & 2.86 & 1.94 & 2.34 & 3.35 & 1.48 & 1.84 & 1.61 & 3.75 & 35.07 & - & - \\
\hline SD & 1.06 & 1.03 & .93 & .91 & .77 & .50 & 1.23 & .49 & .95 & 11.00 & - & - \\
\hline
\end{tabular}

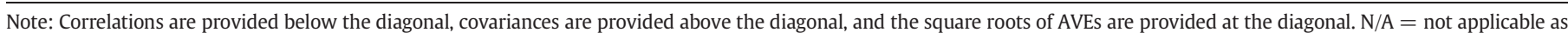
construct measured by single item. All correlations are significant at .05 level. 
Table 2

Measures, factor loadings, and composite reliabilities.

\begin{tabular}{|c|c|c|c|c|}
\hline \multirow[t]{2}{*}{ Source } & \multirow[t]{2}{*}{ Constructs } & \multicolumn{2}{|c|}{$\begin{array}{l}\text { Construct } \\
\text { loading }\end{array}$} & \multirow[t]{2}{*}{ C.R } \\
\hline & & $\lambda$ & AVES & \\
\hline \multicolumn{5}{|l|}{ Antecedents } \\
\hline $\begin{array}{l}\text { Escalas and Bettman (2003);Rindfleisch, } \\
\text { Burroughs, and Wong (2009) }\end{array}$ & $\begin{array}{l}\text { Self-brand connection - measures the extent to which a consumer has incorporated a brand into his or her } \\
\text { self-concept. } \\
\text { - The luxury brand reflects who I am. } \\
\text { - I can identify with the luxury brand. } \\
\text { - I feel a personal connection to the luxury brand. } \\
\text { - I ( can) use this luxury brand to communicate who I am to other people. } \\
\text { - I consider this luxury brand to be "me". }\end{array}$ & $\begin{array}{l}.90 \\
.86 \\
.91 \\
.85 \\
.88\end{array}$ & .77 & .94 \\
\hline \multicolumn{5}{|l|}{ Moderators } \\
\hline Dodds, Monroe, and Grewal (1991) & $\begin{array}{l}\text { Value consciousness - measures consumer's assessment of the quality of the product in relation to its price. } \\
\text { - This product is a ( } 1=\text { very poor value for money to } 5=\text { very high value for money). } \\
\text { - At the price shown, the product is ( } 1=\text { very uneconomical to } 5=\text { very economical). } \\
\text { - The product is considered to be a good buy. } \\
\text { - This product appears to be a bargain. } \\
\text { - This price shown for the product is ( } 1=\text { very unacceptable to } 5=\text { very acceptable). }\end{array}$ & $\begin{array}{l}.87 \\
.73 \\
.86 \\
.80 \\
.85\end{array}$ & .68 & .91 \\
\hline & $\begin{array}{l}\text { Impulsive buying - measures consumer's tendency to buy products spontaneously, unreflectively, } \\
\text { immediately and kinetically. }\end{array}$ & & .63 & .92 \\
\hline Rook and Fisher (1995) & $\begin{array}{l}\text { - I often buy things spontaneously. } \\
\text { - "Just do it" describes the way I buy things. } \\
\text { - "I see it, I buy it" describes me. } \\
\text { - "Buy now, think about it later" describes me. } \\
\text { - I buy things according to how I feel at the moment. } \\
\text { - Sometimes I am a bit reckless about what I buy. }\end{array}$ & $\begin{array}{l}.83 \\
.92 \\
.88 \\
.82 \\
.76 \\
.74\end{array}$ & .63 & .83 \\
\hline $\begin{array}{l}\text { Mowen and Spears (1999); Brown, Mowen, } \\
\text { Donavan, and Licata (2002) }\end{array}$ & $\begin{array}{l}\text { Openness to experience }- \text { captures an individual's degree of imagination and originality } \\
\text { How often you experience the following: }(1=\text { never to } 5=\text { always }) \\
\text { - Frequently feel highly creative } \\
\text { - Imaginative } \\
\text { - Feel more original than others }\end{array}$ & $\begin{array}{l}.88 \\
.86 \\
.62\end{array}$ & & \\
\hline \multicolumn{5}{|l|}{ Outcome } \\
\hline Dodds, Monroe, and Grewal (1991) & $\begin{array}{l}\text { Willingness to buy LBC - this measure essentially captures the extent to which consumers' willingness to buy } \\
\text { a counterfeit luxury product after reading the scenario and seeing the pictures. } \\
\text { - The likelihood of purchasing this product ( } 1=\text { very low to } 5=\text { very high }) \\
\text { - The probability that I would consider buying the product ( } 1=\text { very low to } 5=\text { very high) } \\
\text { - I intent to buy this product. } \\
\text { - At this price shown, I would consider buying the product. }\end{array}$ & $\begin{array}{l}.92 \\
.89 \\
.93 \\
.87\end{array}$ & .82 & .95 \\
\hline
\end{tabular}

\subsection{Assessment of common method bias}

Cross-sectional surveys where both the independent and dependent variables came from the same source are susceptible to common method bias (Podsakoff, MacKenzie, Lee, \& Podsakoff, 2003). Thus, we conducted two separate tests to assess the presence of common method bias. First, we employed a CFA-based version of Harmon's one-factor test (McFarlin \& Sweeney, 1992; Sanchez \& Brock, 1996). Results for this model were quite poor and substantially worse than those from the proposed measurement model (chi-square goodness-of-fit index of 4702 with $495^{\circ}$ of freedom; CFI $=0.340$, RMSEA $=0.170$, and SRMR $=0.172$ ), indicating that common method bias is minimal. Second, Lindell and Whitney (2001) marker variable assessment technique was employed. This technique involves assessing the impact of a variable, which is theoretically uncorrelated with the variables in the study, on the correlations among the independent and dependent variables. After partialing out the marker variable, the significance level of all the bivariate correlations remained unchanged. Thus, the assessment of two tests suggests that the risk of common method bias is minimal.

\section{Results}

\subsection{Hypothesis Tests}

Structural equations modeling approach (Anderson \& Gerbing, 1982) using EQS version 6.1 to test the hypotheses. This approach allows accounting for measurement error and simultaneously estimating all direct and interaction effects in the conceptual model. Specifically, we estimated a model based on Ping's $(1995,2007)$ approach for modeling latent variables interactions. Using this approach, three interaction variables were created that accounted for the interaction between SBC and consumer personality traits. In addition to these interaction effects, the direct effects of the four exogenous variables on willingness to buy LBC were also estimated. The structural model was estimated simultaneously with the measurement model using raw data as an input. The overall fit of the data to the hypothesized model was done using Maximum Likelihood, and the resulting fit was satisfactory $\left(\chi^{2}=595, \mathrm{df}=400 ; \mathrm{CFI}=0.98 ;\right.$ SRMR $=.03$; RMSEA $\left.=0.04\right)$. The results are reported in Table 3.

To assess $\mathrm{H} 1-\mathrm{H} 7$, we examined the sign and significance of the coefficients. Overall, the independent variables explained $65 \%$ of the variance in willingness to buy LBC. More detailed results are reported in Table 3 and provide strong support for the direct effect of SBC $(\beta=$ $.29, \mathrm{p}<0.01$ ) on willingness to buy LBC, providing support for H1. Additionally, we find strong support for the direct effect of $\mathrm{VC}(\beta=0.54$, $\mathrm{p}<0.01)$ and impulsive buying $(\beta=0.09, \mathrm{p}<0.05)$ on willingness to buy LBC, hence confirming $\mathrm{H} 2$ and $\mathrm{H} 3$. Unfortunately, our model does not provide support for the direct effect of openness to experience on willingness to buy LBC ( $\beta=-0.02, p>0.05)$. Therefore, no support was found for $\mathrm{H} 4$

With respect to the interaction results, the interaction between SBC and VC on willingness to buy LBC is significant $(\beta=0.18, p<0.01)$, supporting H5. Further, the interactions between SBC and impulsive 
Table 3

Assessment of research hypotheses.

\begin{tabular}{|c|c|c|c|}
\hline Hypotheses & Relationships & CS & Assessment \\
\hline \multicolumn{4}{|l|}{ Self-Concept } \\
\hline H1 & SBC is positively associated with the willingness to buy LBC. & $.29^{* *}$ & Supported \\
\hline \multicolumn{4}{|c|}{ Consumer Personality Traits } \\
\hline $\mathrm{H} 2$ & VC is positively associated with willingness to buy LBC. & $.54^{* *}$ & Supported \\
\hline H3 & Impulsive buying behavior is positively associated with willingness to buy LBC. & $.09^{*}$ & Supported \\
\hline $\mathrm{H} 4$ & Openness to experience is negatively associated with willingness to buy LBC. & n.s. & Not Supported \\
\hline \multicolumn{4}{|c|}{ Interaction/Moderation Effects } \\
\hline H5 & $\begin{array}{l}\text { The combined effect (i.e., interaction effect) of SBC and VC will be positively associated with willingness to } \\
\text { buy LBC. }\end{array}$ & $.18^{* *}$ & Supported \\
\hline H6 & $\begin{array}{l}\text { The combined effect (i.e., interaction effect) of SBC and impulsive buying will be positively associated with } \\
\text { willingness to buy LBC. }\end{array}$ & n.s. & Not Supported \\
\hline H7 & The effect of SBC on willingness to buy LBC will be diminished as openness to experience increases. & $-.12^{*}$ & Supported \\
\hline \multicolumn{4}{|c|}{ 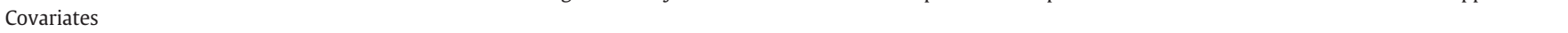 } \\
\hline & Affordability of original product & n.s. & \\
\hline & Prior fake product experience & n.s. & \\
\hline & Propensity to buy authentic products & $-.15^{* *}$ & \\
\hline & Age & $-.07^{*}$ & \\
\hline & Gender & n.s. & \\
\hline & Product types: & & \\
\hline & Watch dummy & $-.11^{*}$ & \\
\hline & Purse dummy & n.s. & \\
\hline
\end{tabular}

Note: $\mathrm{CS}=$ completely standardized path coefficient, n.s. = not significant.

$* \mathrm{p}<.05$.

** $\mathrm{p}<.01$.

buying $(\beta=-.06, p>0.05)$ on willingness to buy LBC is not significant. This means that $\mathrm{H} 6$ is not supported. The interaction effect between SBC and openness to experience is in support of $\mathrm{H} 8(\beta=-.12 \mathrm{p}<0.05)$. However, it is important to note here that since the direct effect of openness to experience on willingness to buy LBC is not significant, openness to experience acts as a doubly exogenous variable that diminishes the effect of SBC on willing to buy LBC. This means that the effect of SBC on willingness is stronger when openness to experience is low, than when it is high.

Lastly, we also tested the effects of control variables. Of all the controls included, consumer's propensity to buy authentic and original products has a negative and significant effect on willingness to buy LBC. Further, we find age has a negative and significant effect on willingness to buy, which indicates that younger consumers are more susceptible to buying counterfeit products than the older consumers. Unlike prior research, we not find significant effect of prior fake experience (Yoo \& Lee, 2012). Lastly, we find that watch product category has a negative and significant effect on the willingness to buy counterfeit product. This may suggest that consumers may not have faith in a counterfeit product that involves difficulty in predicting the performance quality.

\subsection{Probing the interactions}

To improve our understanding of the significant interaction and moderating effects, we conducted simple slopes tests and plotted the interactions graphically (see Fig. 2). These plots were created by adapting the procedure described in Aiken and West (1991), using standardized path coefficients (Cortina, Chen, \& Dunlap, 2001). With respect to the effect proposed in $\mathrm{H} 5$, simple slopes test revealed that SBC only had positive and significant effect on willingness to purchase LBC when VC was high. Thus, for consumers who are not concerned with price, developing strong brand connections doesn't make them more likely to purchase fake goods. For $\mathrm{H7}$, the results show thatat low levels of openness to new experience, SBC had a significant impact on willingness to purchase counterfeits. However, the effect was significant at both high and low levels of openness to experience, but the effect was stronger at lower levels than at higher levels of openness to experience.

\section{Discussion}

The results of this study challenge the current assumption in the literature that shows consumer-brand relationships lead to universally positive developments for brands by empirically demonstrating that SBC has the direct positive effect on consumers' propensity to buy LBC. Additionally, this study takes a step further to understand under what conditions this effect is either enhanced or diminished by consumer personality traits. The results hold important implications for both managers and academics.

\subsection{Research contributions}

This research makes three important contributions to the literature. First, this study is among the few empirical studies to explicitly examine the role of luxury brands in influencing consumers' preference for counterfeit products. The results of the study demonstrate that consumers have a tendency to consider buying LBC to build or reflect their identity to others. This suggests that consumers need to feel a connection with the brand to engage in the process of buying LBC product. Prior research suggests the influence of self-image in buying LBC (Bian \& Moutinho, 2009), and the finding of this study confirms that speculation.

Second, this study makes unique contribution to the literature of consumer-brand relationship. Previous research on consumer-brand relationship has primarily explored the bright side of the formation of consumer-brand relationship (Batra, Ahuvia, \& Bagozzi, 2012; Escalas \& Bettman, 2003; Escalas \& Bettman, 2005). The research is the first to explore the "dark side" of consumer-brand relationship. This research, of course, is not meant to claim that every consumer who builds a relationship with a brand to create self-concept gets persuaded to buy LBC. Rather, the result claims that the susceptibility to consider buying LBC increases for consumers who build interpersonal connections with luxury brands. This finding is in line with the findings of Mazar et al. (2008) that consumers have a tendency to strike a balance between driving some financial benefit and behaving dishonestly without damaging their self-concept.

Third, the research provides conditions under which the strength of the relationship between SBC and willingness to buy LBC varies. The interaction results will help researchers understand consumer dynamics 
A. The Interaction between a SBC and VC on Willingness to Buy LBC

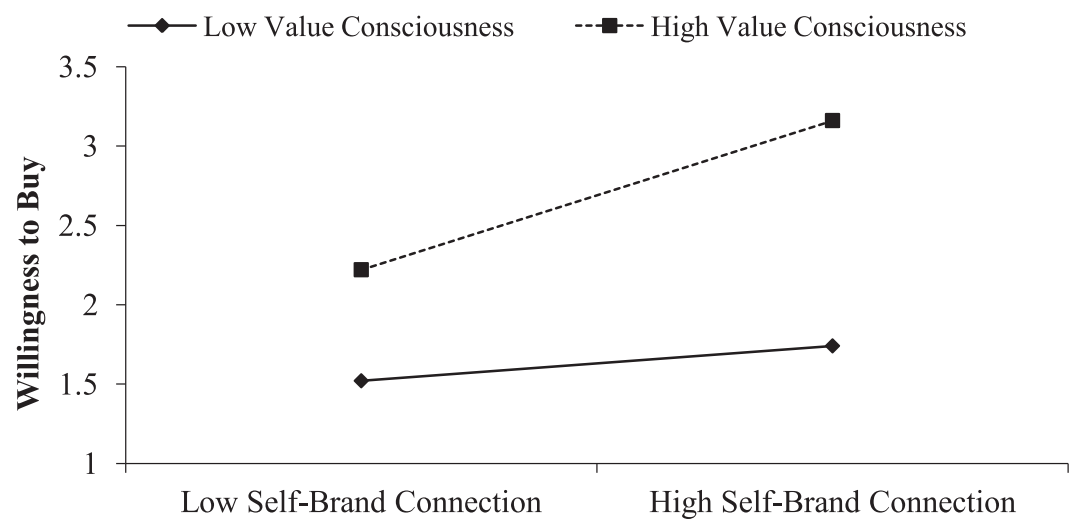

B. The Interaction between a SBC and Openness to Experience on Willingness to Buy LBC

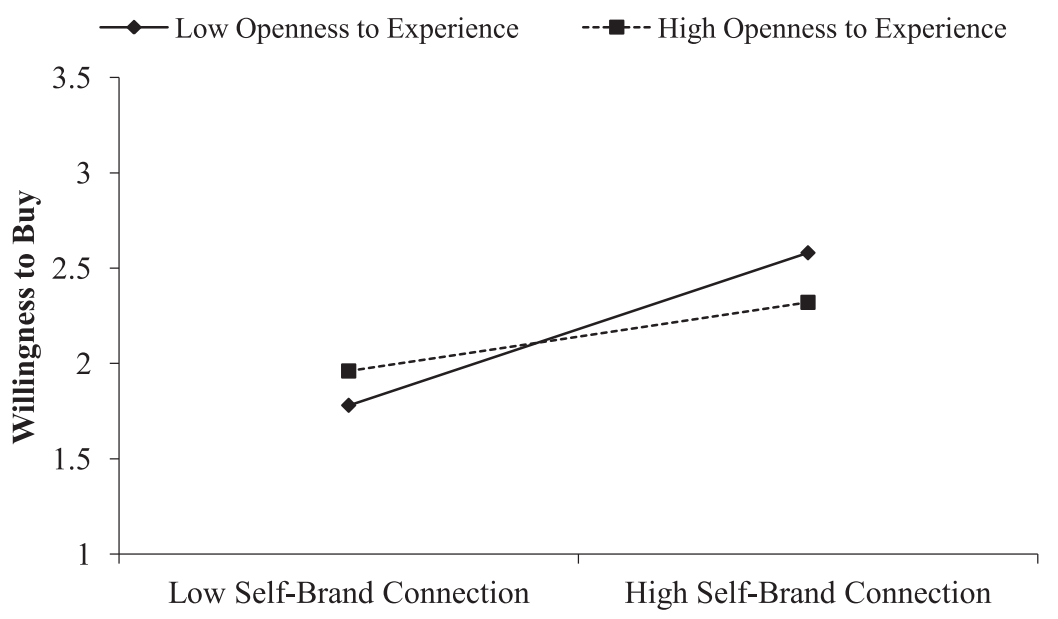

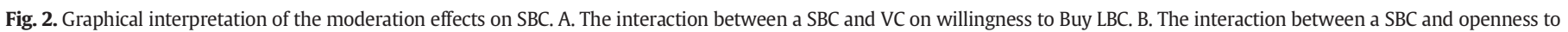
experience on willingness to buy LBC.

from a different perspective than has not been previously explored in both the consumer-brand relationship and counterfeit product literatures. The results show that a consumer with both high SBC and high VC has relatively higher propensity to buy LBC products. However, intriguing conditions are foundthat show consumers that are high on openness to experience are less likely to buy LBC even if they are high on SBC. This finding suggests that researchers have much to learn by understanding consumers' need to be original and find novel solutions to their needs. Consumers who believe in originality see engaging in LBC product purchase of their favorite brands not only as an act of being disloyal toward their brand but also as a tarnish to their self-concept. This finding contributes to the literature on openness to experience, which is labeled as one of the fundamental elements of personality, but with limited understanding in the literature (McCrae, 1996; Woo et al., 2014).

\subsection{Managerial implications}

A concerted effort by brand managers and their salespeople can help create intangible propositions that signal exclusivity, heritage, and customer relationship orientation that will be difficult to be counterfeited. The rise in fake fashion is attributed to consumers' changing attitude toward, "buy now, throw away tomorrow" (Huffington Post, 2013). This suggests that brands need to offer much more than the tangible product in order to stop customers from buying fake products. In the section below, a few key areas for opportunities for both brand managers and salespeople are highlighted.

\subsubsection{Authenticating brand purchases}

As expected, it is found that SBC has a strong influence on consumer's willingness to buy LBC. This suggests that individuals with a high need to create and reflect a unique personal identity are willing to go as far as buying a counterfeit product to fulfill their objective. This finding suggests that managers need to create a brand image that conveys a message of exclusivity that can only be experienced by the use of the original product. Brand managers can effectively accomplish this objective by closely working with salespeople who can reinforce the concept of exclusivity by creating loyalty initiatives that provide special privileges to the shoppers. For example, giving shoppers the ability to put products on hold for more than a week, extended return policy, and/or special assistance provided to make the shopping experience more effective and memorable. In instances where simply developing the image cannot curtail interest in counterfeits, the brands could find new, creative ways to socially authenticate purchases for their customers. Because, counterfeiters have become so skilled in replicating the actual products, brands need to provide authentication via means that are completely internal to their ecosystem. One opportunity along these lines could be public validation of a branded purchase via social media. This would not only allow the brand to provide the consumer 
with further validation of their purchase in a media that is easily shared with their friends, but also help the retailer to attract customers to its store.

\subsubsection{Creating a shopping confidante}

Many salespeople nowadays are have started building relationships with their customers by making house calls, texting photos of the product, friending customers on Facebook, and giving in-store and online product advice (The Wall Street Journal, 2013). These strategies will allow the salespeople to not only woo customers, but can also be used to curb counterfeit product purchases. Salespeople can leverage these findings to better profile customers for effective results in building both customer behavioral and attitudinal loyalties. One of the results in our study shows that open customers are less likely to buy counterfeit products because such products do not allow consumers to express their true self to others. While it would be difficult for salespeople to identify these consumers for a targeted marketing campaign, salespeople can leverage this finding when working closely with customers to increase connections. Additionally, by simply reminding consumers that they should do the right thing to support the brand as part of these branded experiences, they could change this negative behavior (Mazar et al., 2008).

\subsection{Future research and limitations}

This study, while offering many insights, has some limitations or rather opportunities for future research, as well. First, the consumers were shown pictures of the product rather than the actual products. Since there is high potential for consumers to act differently in an actual shopping situation, future research must be done to observe or create actual shopping experiences. Second, the study could not capture how a customer will behave when they buy these products online and with money back guarantee. With the growth of e-commerce, most of the counterfeit products are being sold online. It would be interesting to explore how online shopping impacts consumer attitude toward buying LBC. Will it enhance or diminish such behaviors? Third, the study only incorporated three brands and product categories. Futures research can incorporate more brands and product categories to present a more comprehensive view of the impact of LBC.

\section{References}

Aaker, J.L. (1997). Dimensions of brand personality. Journal of Marketing Research, 34, 347-356.

Aiken, L.S., \& West, S.G. (1991). Multiple regression: Testing and interpreting interactions. Sage Publications.

Albers-Miller, N.D. (1999). Consumer misbehavior: Why people Buy illicit goods. Journal of Consumer Marketing, 16(3), 273-287.

Anderson, J.C., \& Gerbing, D.W. (1982). Some methods for respecifying measurement models to obtain unidimensional construct measurement. Journal of Marketing Research, 19(4), 453-460.

Bagozzi, R.P., \& Yi, Y. (2012). Specification, evaluation, and interpretation of structural equation models. Journal of the Academy of Marketing Science, 40, 8-34.

Bagozzi, R.P., Yi, Y., \& Phillips, L.W. (1991). Assessing construct validity in organizational research. Administrative Science Quarterly, 36(3), 421-458.

Batra, R., Ahuvia, A., \& Bagozzi, R.P. (2012). Brand love. Journal of Marketing, 76(2), 1-16.

Belk, R.W. (1988, September). Possessions and the extended self. Journal of Consumer Research, 15, 139-168.

Bian, X., \& Moutinho, L. (2009). An investigation of determinants of counterfeit purchase consideration. Journal of Business Research, 62(3), 368-378.

Bloch, P.H., Bush, R.F., \& Campbell, L. (1993). Consumer 'accomplices' in product counterfeiting. Journal of Consumer Marketing, 10(4), 27-36.

Bodner, R., \& Prelec, D. (2002). Self-signaling and diagnostic utility in everyday decision making. In I. Brocas, \& J. Carillo (Eds.), Collected essays in psychology and economics (pp. 105-123). Oxford, England: Oxford University Press.

Brown, T.J., Mowen, J.C., Donavan, D.T., \& Licata, J.W. (2002). The customer orientation of service workers: Personality trait effects on self- and supervisor performance ratings. Journal of Marketing Research, 39(1), 110-119.

Buhrmester, M., Kwang, T., \& Gosling, S.M. (2011). Amazon's mechanical Turk: A new source of inexpensive, yet high-quality, data? Perspectives on Psychological Science, 6, 3-5.

Chakraborty, G., Allred, A.T., \& Bristol, T. (1996). Exploring consumers' evaluations of counterfeits: The roles of country of origin and ethnocentrism. In Kim Corfman, \&
John Lynch (Eds.), Advances in Consumer Research, 23. (pp. 379-384). Provo, UT: AssocConsumRes.

Cheung, W.L., \& Prendergast, G. (2006). Buyers' perceptions of pirated products in China, Marketing Intelligence \& Planning, 24(5), 446-462.

Chuchinprakarn, S. (2003). Consumption of counterfeit goods in Thailand: Who are the patrons? Europe Advanced Consumer Research, 6, 48-53.

Cordell, V.V., Wongtada, N., \& Kieschnick, R.L. (1996). Counterfeit purchase intentions: Role of lawfulness attitudes and product traits as determinants. Journal of Business Research, 35(1), 35-41.

Cortina, J.M., Chen, G., \& Dunlap, W.P. (2001, October). Testing interaction effects in LISREL: Examination and illustration of available procedures. Organizationa Research Methods, 4, 324-360.

Costa, P.T., Jr., \& McCrae, R.R. (1992). Revised NEO personality inventory and NEO five-factor inventory professional manual. Odessa, FL: Psychological Assessment Resources.

Dodds, W.B., Monroe, K.B., \& Grewal, D. (1991). Effects of price, brand, and store information on buyers product evaluations. Journal of Marketing Research, 28(3), 307-319.

Dodge, H.R., Edwards, E.A., \& Fullerton, S. (1996). Consumer transgressions in the marketplace: consumers' perspectives. Psychology and Marketing, 13(8), 821-835.

Eisend, M., \& Schuchert-Güler, P. (2006). Explaining counterfeit purchase: a review and preview. Academy of Marketing Science Review, 12, 1-26.

Escalas, J.E., \& Bettman, J.R. (2003). You are what they eat: The influence of reference groups on consumer connections to brands. Journal of Consumer Psychology, 13(3), 339-348.

Escalas, J.E., \& Bettman, J.R. (2005, December). Self-construal, reference groups, and brand meaning. Journal of Consumer Research, 32, 378-389.

Fiske, S.T., \& Taylor, S.E. (1991). Social cognition. NewYork: McGraw-Hill.

Fornell, C., \& Larcker, D.F. (1981). Structural equation models with unobservable variables and measurement error: Algebra and statistics. Journal of Marketing Research, 18(3), 382-388.

Fournier, S. (1998). Consumers and their brands: Developing relationship theory in consumer research. Journal of Consumer Research, 24, 343-373.

Geiger-Oneto, S., Gelb, B.D., Walker, D., \& Hess, J.D. (2012, October). "Buying status” by choosing or rejecting luxury brands and their counterfeits. Journal of the Academy of Marketing Science, 40, 357-372.

Grossman, G.M., \& Shapiro, C. (1988, March). Counterfeit-product trade. The American Economic Review, 78, 59-75.

Han, Y.J., Nunes, J.C., \& Drèze, X. (2010). Signaling status with luxury goods: The role of brand prominence. Journal of Marketing, 74(4), 15-30.

Hoch, S.J., \& Loewenstein, G. (1991). Time-inconsistent preferences and consumer selfcontrol. Journal of Consumer Research, 17(4), 492-507.

Hoe, L., Hogg, G., \& Hart, S. (2003). Fakin' it: Counterfeiting and consumer contradictions, In Darach Turley, \& Stephen Brown (Eds.), European Advances in Consumer Research, 6. (pp. 60-67). Provo, UT: Assoc Consum Res.

Huang, H.H., Mitchell, V.W., \& Rosenaum-Elliott, R. (2012). Are consumer and brand personalities the same? Psychology and Marketing, 29(5), 334-349.

Huffington Post (). Counterfeit fashion goods are on the rise, thanks to pressured wallets and fast fashion. Accessed June 5, 2013. Downloaded from: http://www.huffingtonpost.co.uk/ 2013/02/13/counterfeit-fashion-goods_n_2678560.html

International AntiCounterfeiting Coalition (). About counterfeiting. Accessed May 21, 2012. Downloaded from: https://iacc.org/about-counterfeiting/

Kacen, I.I., \& Lee, J.A. (2002). The influence of culture on consumer impulsive buying behavior. Journal of Consumer Psychology, 12, 163-716.

Kukar-Kinney, M., Ridgway, N.M., \& Monroe, K.B. (2012). The role of price in the behavior and purchase decisions of compulsive buyers. Journal of Retailing, 88(1), 63-71.

Lai, K.K.Y., \& Zaichkowsky, J.Y. (1999). Brand imitation: Do the Chinese have different views? Asia Pacific Journal of Management, 16(2), 179-192.

Leisen, B., \& Nill, A. (2001). Combating product counterfeiting: An investigation into the likely effectiveness of a demand-oriented approach. In R. Krishnan, \& M. Viswanathan (Eds.), AMA Winter Educators' Conference Proceedings, 12. (pp. 271-277). Chicago: American Marketing Association.

Lichtenstein, D.R., Netemeyer, R. G., \& Burton, S. (1990, July). Distinguishing coupon proneness from value consciousness: An acquisition-transaction utility theory perspective. Journal of Marketing, 54, 54-67.

Lichtenstein, D.R., Ridgway, N.M., \& Netemeyer, R.G. (1993). Price perceptions and consumer shopping behavior: A field study. Journal of Marketing Research, 30, 234-245.

Lin, L.Y. (2010). The relationship of consumer personality trait, brand personality and brand loyalty: an empirical study of toys and video games buyers. The Journal of Product and Brand Management, 19(1), 4-17.

Lindell, M.K., \& Whitney, D.J. (2001). Accounting for common method in cross-sectional research designs. The Journal of Applied Psychology, 86(1), 114-121.

Matzler, K., Bidmon, S., \& Grabner-Krauter, S. (2006). Individual determinants of brand affect: The role of the personality traits of extroversion and openness to experience. The Journal of Product and Brand Management, 15(7), 427-434

Mazar, N., Amir, O., \& Ariely, D. (2008). The dishonesty of honest people: A theory of selfconcept maintenance. Journal of Marketing Research, 45(6), 633-644.

McCrae, R.R. (1987). Creativity, divergent thinking, and openness to experience. Journal of Personality and Social Psychology, 52(6), 1258-1265.

McCrae, R.R. (1996). Social consequences of experiential openness. Psychological Bulletin, 120, 323-337.

McCrae, R.R. (2009). The five-factor model of personality traits: Consensus and controversy. In P. Corr, \& G. Matthews (Eds.), The Cambridge handbook of personality psychology. Cambridge: Cambridge University Press.

McCrae, R.R., \& Costa, P.T., Jr. (1997). Conceptions and correlates of openness to experience. In R. Hogan, J. Johnson, \& S. Briggs (Eds.), Handbook of personality psychology (pp. 825-847). San Diego, CA: Academic Press. 
McFarlin, D.B., \& Sweeney, P.D. (1992). Distributive and procedural justice as predictors of satisfaction with personal and organizational outcomes. Academy of Management Journal, 35(3), 626-637.

Monroe, K.B. (1979). Price as an index of value. Pricing: Making Profitable Decisions. New York: McGraw-Hill Book Company, 37-48.

Mowen, J.C., \& Spears, N. (1999). A hierarchical model approach to understanding compulsive buying among college students. Journal of Consumer Psychology, 8(4), 407-430.

Nia, A., \& Zaichkowsky, J.Y. (2000). Do counterfeits devalue the ownership of luxury brands? The Journal of Product and Brand Management, 9(7), 485-497.

Penz, E., \& Stottinger, B. (2005). Forget the "real" thing - take the copy! An exploratory model for the volitional purchase of counterfeit products. Advances in Consumer Research, 32, 568-575.

Phau, I., \& Teah, M. (2009). Devil wears (counterfeit) Prada: A study of antecedents and outcomes of attitudes towards counterfeits of luxury brands. Journal of Consumer Marketing, 26(1), 15-27.

Ping, R.A. (1995, August). A parsimonious estimating technique for interaction and quadratic latent variables. Journal of Marketing Research, 32, 336-347.

Ping, R.A. (2007). In Andrea L. Dixon, \& Karen A. Machleit (Eds.), Second-Order Latent Variables: Interactions, Specifications, Estimation, and an Example in Marketing Theory and Applications, vol. 18. (pp. 286-293). Chicago: American Marketing Association.

Poddar, A., Foreman, J., Banerjee, S., \& Ellen, P.S. (2012). Exploring the Robin Hood effect: Moral profiteering motives for purchasing counterfeit products. Journal of Business Research, 65(10), 1500-1506.

Podsakoff, P.M., MacKenzie, S.B., Lee, J.Y., \& Podsakoff, N.P. (2003). Common method biases in behavioral research: A critical review of the literature and recommended remedies. The Journal of Applied Psychology, 88(5), 879-903.

Puntoni, S. (2001). Self-identity and purchase intention: An extension of the theory of planned behaviour. Europe Advanced Consumer Research, 5, 130-134.

Ramanathan, S., \& Menon, G. (2006, November). Time-varying effects of chronic hedonic goals on impulsive behavior. Journal of Marketing Research, 43, 628-641.

Richins, M.L. (1994, December). Valuing things: The public and private meanings of possessions. Journal of Consumer Research, 21, 504-521.

Rindfleisch, A., Burroughs, J.E., \& Wong, N. (2009). The safety of objects: Materialism, existential insecurity and brand connection. Journal of Consumer Research, 36(1), 1-16.

Rook, D.W., \& Fisher, R.J. (1995). Normative influences on impulsive buying behavior. Journal of Consumer Research, 22(3), 305-313.
Rosenbaum, M., Ronald, K. \& Wooldridge, B.R. (2011). Understanding unethical retail disposition practice and restraint from the consumer perspective. Psychology and Marketing, 28(1), 29-52.

Rosenberg, M. (1979). Conceiving the self. New York: Basic Books.

Sanchez, J.I., \& Brock, P. (1996). Outcomes of perceived discrimination among Hispanic employees: Is diversity management a luxury or a necessity? Academy of Management Journal, 39(3), 704-719.

Sirgy, J.M. (1982, December). Self-concept in consumer behavior: A critical review. Journal of Consumer Research, 9, 287-300.

Sirgy, J.M., Johar, J.S., Samli, A.C., \& Claiborne, C.B. (1991). Self-congruity versus functional congruity: Predictors of human behavior. Journal of the Academy of Marketing Science, 19, 363-375.

Speights, D., \& Hilinski, M. (2005). Return fraud and abuse: How to protect profits. Retailing Issues Letter, 17(1), 1-6.

Stern, H. (1962). The significance of impulse buying today. Journal of Marketing, 26, 59-62.

The Wall Street Journal. A Shopping Confidante. Published in the Personal Journal Section December 4, 2013.

Tom, G., Garibaldi, B., Zeng, Y., \& Pilcher, J. (1998). Consumer demand for counterfeit goods. Psychology and Marketing, 15(5), 405-421.

Turunen, L.L.M., \& Laaksonen, P. (2011). Diffusing the boundaries between luxury and counterfeits. The Journal of Product and Brand Management, 20(6), 468-474.

Wiedmann, K.P., Hennigs, N., \& Siebels, A. (2009). Value-based segmentation of luxury consumption behavior. Psychology and Marketing, 26(7), 625-651.

Wilcox, K., Hyeong, M.K., \& Sen, S. (2009, April). Why do consumers buy counterfeit luxury brands. Journal of Marketing Research, 46, 247-259.

Woo, S.E., Chernyshenko, O.S., Longley, A., Zhang, Z.X., Chiu, C.Y., \& Stark, S.E. (2014). Openness to experience: Its lower level structure, measurement, and cross-cultural equivalence. Journal of Personality Assessment, 96(1), 29-45.

Woo, S. E., Chernyshenko, O. S., Longley, A., Zhang, Z. X., Chiu, C. Y., \& Stark, S. E. (2014). Openness to experience: Its lower level structure, measurement, and cross-cultural equivalence. Journal of Personality Assessment, 96, 29-45.

Yoo, B., \& Lee, S.H. (2012). Asymmetrical effects of past experiences with genuine fashion luxury brands and their counterfeits on purchase intention of each. Journal of Business Research, 65(10), 1507-1515.

Zhang, Y., \& Shrum, L.J. (2009). The influence of self-construal on impulsive consumption. Journal of Consumer Research, 35(5), 838-850. 